\title{
Analysis of propagule pressure and genetic diversity in the invasibility of a freshwater apex predator: the peacock bass (genus Cichla)
}

\author{
Daniel C. Carvalho ${ }^{1,2,3}$, Denise A. A. Oliveira ${ }^{1}$, Iracilda Sampaio ${ }^{4}$, \\ and Luciano B. Beheregaray ${ }^{2}$
}

An important step in invasive biology is to assess biological variables that could be used to predict invasion success. The study of genetics, evolution, and interactions of invasive and native species in invaded ranges provides a unique opportunity to study processes in population genetics and the capability of a species' range expansion. Here, we used information from microsatellite DNA markers to test if genetic variation relates to propagule pressure in the successful invasion of an apex predator (the Amazonian cichlid Cichla) into Southeastern Brazilian River systems. Invasive populations of Cichla have negatively impacted many freshwater communities in Southeastern Brazil since the 1960s. Reduction of genetic variation was observed in all invasive populations for both Cichla kelberi (CK) and Cichla piquiti (CP). For instance, heterozygosity was lower in the invasive range when compared to native populations from the Amazon basin $\left(\mathrm{CP} \mathrm{H}_{\mathrm{E}}=0.179 / 0.44 ; \mathrm{CK} \mathrm{H}_{\mathrm{E}}=0.258 / 0.536\right.$ respectively). Therefore, despite the successful invasion of Cichla in southeast Brazil, low genetic diversity was observed in the introduced populations. We suggest that a combination of factors, such as Cichla's reproductive and feeding strategies, the "evolutionary trap" effect and the biotic resistance hypothesis, overcome their depauperete genetic diversity, being key aspects in this apex predator invasion.

Uma importante etapa na biologia da invasão é acessar variáveis biológicas que podem predizer o sucesso de invasão. O estudo da genética, evolução e interações entre invasores e espécies nativas no ambiente invadido pode prover uma oportunidade única para o estudo dos processos em genética de populações e a capacidade de uma espécie ampliar seu habitat. Nesse trabalho, nos utilizamos dados de marcadores de DNA microssatélites para testar se a variação genética é relacionada a pressão de propágulo na invasão bem sucedida do predador de topo (o ciclídeo Amazônico Cichla) nos rios do Sudeste Brasileiro. Populações invasoras de Cichla vem impactando negativamente diversas comunidades de água doce no Sudeste brasileiro deste 1960. A redução da variação genética foi observada em todas populações invasoras, tanto para Cichla kelberi (CK) como Cichla piquiti (CP). Por exemplo, a heterozigose foi menor no ambiente invadido quando comparada com as populações nativas da bacia Amazônica ( $\mathrm{CP} \mathrm{HE}=0.179 / 0.44 ; \mathrm{CK} \mathrm{HE}=0.258 / 0.536$ respectivamente $)$. Assim, apesar do sucesso da invasão de Cichla no sudoeste do Brasil, baixa diversidade genética foi observada nas populações introduzidas. Nós sugerimos que uma combinação de fatores, como as estratégias reprodutivas de Cichla, o efeito de "armadilha evolutiva" e a hipótese de resistências biótica superam o efeito que a diversidade genética depauperada exerce, sendo aspectos-chave na invasão desse predador de topo de cadeia.

Key words: Invasion biology, Neotropical, Population genetics, Translocation, Tucunaré.

\section{Introduction}

Invasive species could be treated as natural experiments that provide a unique opportunity to study basic processes in population genetics and the capability of range expansion
(Sakai et al., 2001; Sax et al., 2005). Introduction of a small number of individuals into a new environment has been considered a potential limitation to the establishment of a species, since adaptive evolutionary changes required by novel selection pressures need enough genetic variation

\footnotetext{
${ }^{1}$ Departamento de Zootecnia, Escola de Veterinária, Universidade Federal de Minas Gerais, Belo Horizonte, MG, Brazil.

${ }^{2}$ Molecular Ecology Laboratory, Flinders University, Adelaide, SA, Australia.

${ }^{3}$ Pontifícia Universidade Católica de Minas Gerais, Programa de Mestrado em Zoologia de Vertebrados. Belo Horizonte, MG, Brazil. danielcarvalho@pucminas.br

${ }^{4}$ Laboratório de Genética e Biologia Molecular, Instituto de Estudos Costeiros, Universidade Federal do Pará, Câmpus de Bragança, Bragança, PA, Brazil.
} 
to take place (Okada et al., 2009; Suarez \& Tsutsui, 2008). This fact leads to the genetic paradox in invasion biology: how invasive species with low genetic variation due to bottlenecks after founder effects are able to persist and adapt to novel conditions and evolutionary challenges (Allendorf \& Lundquist, 2003; Kolbe et al., 2004; Sakai et al., 2001). Kolbe et al. (2004) have shown that multi-introductions are key to invasion success. However, the influence of multiple introductions (i.e., intense propagule pressure) and the invasive genetic paradigm have not yet been resolved since spatial and temporal aspects of multiple introductions were also associated with propagule pressure and the ability of a species to spread (Dlugosch \& Parker, 2008). Genetic data have been useful to provide information on the frequency in which a species is introduced into a specific area, the size of introductions and the subsequent pattern of genetic structure in the new range (Banks et al., 2010; Carvalho et al., 2009b; Dlugosch \& Parker, 2008; Henry et al., 2009). Nonetheless, it is yet unclear what role genetics may have in the propagule pressure effect (Allendorf \& Lundquist, 2003).

An important step in invasive biology is to assess which biological variables are useful to predict which species could potentially become invasive (Lockwood et al., 2005). The genetic diversity of an invasion measured by neutral markers (i.e., parts of the genome that are not under natural selection) vary from unexpected low (Gaskin et al., 2012; Valiente et al., 2010) to high (Kolbe et al., 2004a), and therefore may not be a good predictor of invasion success. However, genetic diversity can be useful in management and control decisions (Sakai et al., 2001; Gaskin, 2012).

The Cichla (peacock bass or tucunaré) is an indigenous Amazonian cichlid fish that was introduced into river basins outside their native range, both in Brazil and in other countries, whereupon they have often become invasive and implicated in local extinctions (Latini \& Petrere, 2004; Zaret \& Paine, 1973). Established invasive populations of Cichla were first recorded in southeastern Brazil in the 1960s (Agostinho et al., 1994), and since then several impacts of this apex predator on indigenous fish populations have been reported (Latini \& Petrere, 2004; Pompeu \& Godinho, 2001), such as biotic homogenization (Zaret \& Paine, 1973; Latini \& Petrere, 2004) and impacting native fish diversity (Godinho et al., 1994; Santos et al., 1994). Moreover, the biological characteristics of Cichla species have made their populations capable of expanding rapidly in the invasive range, especially in modified ecosystems such as hydroelectric reservoirs, pristine floodplains and lagoons (Espinola et al., 2010; Zaret \& Paine, 1973). These include reproductive activity during almost the entire year (Vieira et al., 2009), bi-parental care of eggs and capability to rear young in oxygen-depleted lakes (Zaret, 1980), opportunistic feeding behavior - it preys on whatever it can swallow (Resende et al., 2008), cannibalism (Gomiero \& Braga, 2004), and phenotypic plasticity that allowed adaptation to harsh ecological conditions (Chellappa et al., 2003). While Cichla species were apparently introduced into northeastern Brazil in the late 1940s by government agencies for establishing fish breeding farms, no information was available regarding their origin. Applying a molecular phylogenetic analysis based on mitochondrial $16 \mathrm{~S}$ ribosomal DNA and control region sequences (Carvalho et al., 2009b) identified the source of Cichla species introduced in four different river basins in Southern Brazil. Introductions were likely carried out from a single river, the Tocantins River (Amazon basin). A low diversity of maternal lineages was detected in the invasive populations, except for the reservoir closest to the source population, suggesting different propagule pressures in the invasive range (Carvalho et al., 2009b).

Karyological evidence for interspecific hybridization, intermediate morphology and hybrids have been detected in the peacock bass native range, suggesting hybridization between the sympatric species (Brinn et al., 2004). Natural fertile hybrids between $C$. cf. monoculus and Cichla sp. in the invasive range (Itaipu hydroelectric reservoir and in the floodplain of the upper Paraná River) together with multiple introductions of Cichla species in the Paraná and Parapanema River basin was also reported (Oliveira et al., 2006).

Several aspects of why Cichla's invisibility was so successful in Southeastern Brazil have been investigated, but no correlation with propagule pressure (Espinola et al., 2010) or with the prey naiveté hypothesis (i.e., prey are unable to recognize and respond to predators due to lack of previous ontogenetic contact to a sympatric predator (Kovalenko et al., 2010) have been found. In the latter work, the different co-evolutionary history with a certain predator archetype was not found to explain local extinctions after introduction of $C$. kelberi. The latter was proposed based on behavioral experiments conducted in laboratory where non-native peacock bass could be recognized as a predator by native species (Kovalenko et al., 2010).

Here, we used microsatellite DNA markers to assess genetic diversity in native and introduced populations of two Cichla species: C. kelberi (Kullander \& Ferreira, 2006) and C. piquiti (Kullander \& Ferreira, 2006) and address the following questions: (1) Are there genetic differences between invasive and non-invasive populations of these species? (2) Is hybridization occurring in the native or invaded range? (3) Is genetic diversity correlated with invasiveness of Cichla in non-pristine (i.e., reservoirs) and pristine areas (i.e., natural lakes)? Assessing how multiple introductions (i.e., intense propagule pressure), hybridization and genetic diversity are related to the invasive genetic paradigm might provide insights into the high invasibility success and adaptability of Cichla into new habitats and assist in management decisions. 


\section{Material and Methods}

\section{Sampling}

Fin clips from Cichla piquiti (CP) and Cichla kelberi (CK) were collected and preserved in $90 \%$ ethanol from the Amazon basin (Tucuruí reservoir, $\mathrm{n}=38$ ) in the easternmost native range of the species and from five populations in the invasive range in Southeastern Brazil (non-Amazonian rivers, $\mathrm{n}=84$ ). Samples from the invasive range were collected in four different river systems and include populations from impacted sites (i.e., hydroelectrical reservoirs) and pristine sites (one natural lake and one marginal lagoon) for both species (Table 1; Fig. 1).

\section{Genetic methods}

Tissue samples were digested using proteinase $\mathrm{K}$, and DNA isolated by phenol/chloroform purification (Sambrook et al., 1989). A set of eight microsatellite previously described for $\mathrm{CP}$ and successfully cross-amplified in CK (Carvalho et al., 2009a) were amplified by the Polymerase Chain Reaction (PCR) for all samples. Amplification followed the method described by (Schuelke, 2000) in which PCR products are fluorescently labeled through the inclusion of a third (fluorescent M13) primer in each reaction. Reactions were performed in a final volume of $10 \mu$ containing $1 \mathrm{X}$ Flexi Buffer GoTaq (Promega), $2.5 \mathrm{~mm} \mathrm{MgCl}_{2}, 0.2 \mathrm{~mm}$ dNTPs, 0.2 U Go-Taq Flexi DNA polymerase (Promega), BSA $(0.1 \%), 0.05 \mu \mathrm{M}$ forward primer, $0.2 \mu \mathrm{m}$ reverse primer and
$0.2 \mu \mathrm{m}$ fluorescent M13 primer. The PCR amplifications followed the $63^{\circ} \mathrm{C}-55^{\circ} \mathrm{C}$ touchdown of (Beheregaray \& Sunnucks, 2000). Amplification products were separated on an ABI 3130 genetic analyzer (Applied Biosystems) at the DNA Sequencing Facility of Macquarie University. The resulting microsatellite profiles were examined using genemapper 4.0 (Applied Biosystems) and peaks were scored manually.

\section{Data analysis}

We used genepop v3.4 (Rousset, 2008) to estimate expected $\left(H_{\mathrm{E}}\right)$ and observed $\left(H_{\mathrm{O}}\right)$ heterozygosities, inbreeding coefficient $\left(\mathrm{F}_{\mathrm{IS}}\right)$, number of alleles $\left(\mathrm{N}_{\mathrm{A}}\right)$ and Hardy-Weinberg proportions. Allelic richness $\left(\mathrm{R}_{\mathrm{A}}\right)$ was estimated in Fstat 2.9 (Goudet, 1995). Bonferroni corrections were applied when conducting multiple statistical tests (Rice 1989). Scoring errors, large allele dropout and null alleles were checked employing the program Microcheker (Van Oosterhout et al., 2004) and Inest (Chybicki \& Burczyk, 2009).

To assess possible reductions in diversity related to the process of introduction we first compared allelic richness $\left(\mathrm{R}_{\mathrm{A}}\right)$ and Nei's gene diversity averaged $\left(\mathrm{H}_{\mathrm{E}}\right.$. Differences in $R_{\mathrm{A}}$ and $H_{\mathrm{E}}$ were assessed using the Kruskal-Wallis test to compare native $v s$ invasive population samples; whereas the Dunn's procedure (two tailed test) was used to estimate significant differences between populations using the software Xslstat ${ }^{\mathrm{O}}$.

Levels of population genetic structure in each species were estimated by computing Weir's $\mathrm{F}_{\mathrm{ST}}$ using Genepop 3.4 (Rousset, 2008) and statistical significance estimated with

Table 1. Measures of genetic diversity for the two species of Cichla. Number of samples $(\mathrm{N})$, mean allele richness $\left(\mathrm{R}_{\mathrm{A}}\right)$, mean Nei's genetic diversity $\left(\mathrm{H}_{\mathrm{E}}\right)$, mean number of private alleles per population $\left(\mathrm{N}_{\mathrm{PA}}\right)$, mean Inbreed coefficient $\left(\mathrm{F}_{\mathrm{IS}}\right)$, percentage of polymorphic loci (\% poli Loci), probability (p-value) of rejecting the HWE equilibrium for each population and number of Control region mtDNA haplotypes $(h)$, data from Carvalho et al. (2009). Statistical significance differences between populations of $\mathrm{H}_{\mathrm{E}}$ and $\mathrm{R}_{\mathrm{A}}$ are presented. Identical letters within species indicate similar statistical values, whereas, distinct letters indicate values with significantly statistical difference.

\begin{tabular}{|c|c|c|c|c|c|c|c|c|c|c|c|c|}
\hline Pop & Location & River Basin & Species & Type & $\mathbf{N}$ & $\begin{array}{c}\text { Mean } \\
\mathrm{H}_{\mathrm{E}}\end{array}$ & $\begin{array}{c}\text { Mean } \\
\mathbf{R}_{\mathrm{A}}\end{array}$ & $\begin{array}{c}\text { Mean } \\
\mathbf{N}_{\mathrm{PA}} \\
\end{array}$ & $\begin{array}{c}\text { Mean Fis } \\
\text { (GENEPOP/Inest) }\end{array}$ & $\begin{array}{l}\text { \% poli } \\
\text { Loci }\end{array}$ & $\begin{array}{c}\text { HWE } \\
\text { (p-value) }\end{array}$ & h \\
\hline \multicolumn{13}{|c|}{ Native } \\
\hline TO & Tocantins & Amazonas & C. kelberi & Reservoir & 18 & $0.536^{\mathrm{A}}$ & $3.68^{\mathrm{A}}$ & 2.55 & $0.425 / 0.046$ & 77.78 & $0.000 *$ & 3 \\
\hline TO & Tocantins & Amazonas & C. piquiti & Reservoir & 20 & 0.44 & $2.99^{\mathrm{C}}$ & 3.33 & $0.279 / 0.039$ & 88.89 & $0.000^{*}$ & 6 \\
\hline \multicolumn{13}{|c|}{ Invasive } \\
\hline ITU & Itumbiara & Upper Paraná & C. kelberi & Reservoir & 18 & $0.393^{\mathrm{A}}$ & $2.63^{\mathrm{AB}}$ & 1.11 & $0.28 / 0.046$ & 77.78 & $0.000 *$ & 3 \\
\hline TRM & $\begin{array}{c}\text { Três } \\
\text { Marias }\end{array}$ & São Francisco & C. kelberi & Reservoir & 16 & $0.2^{\mathrm{B}}$ & $1.64^{\mathrm{B}}$ & 0.33 & $0.44 / 0.046$ & 66.67 & $0.0002 *$ & 1 \\
\hline RD & Rio Doce & Doce & C. kelberi & Lake & 15 & $0.182^{\mathrm{B}}$ & $1.5^{\mathrm{B}}$ & 0.11 & $0.23 / 0.052$ & 55.56 & 0.2165 & 1 \\
\hline ITU & Itumbiara & Paraná & C. piquiti & Reservoir & 14 & $0.07^{\mathrm{D}}$ & $1.28^{\mathrm{D}}$ & 0.56 & $0.161 / 0.036$ & 33.33 & 0.2636 & 1 \\
\hline ML & $\begin{array}{l}\text { Marginal } \\
\text { lake - São } \\
\text { Francisco }\end{array}$ & São Francisco & C. piquiti & Lake & 11 & $0.028^{\mathrm{D}}$ & $1.12^{\mathrm{D}}$ & 0.11 & $-0.0714 / 0.037$ & 11.11 & 1.000 & 1 \\
\hline FUR & Furnas & Upper Paraná & C. piquiti & Reservoir & 10 & $0.169^{\mathrm{CD}}$ & $1.59^{\mathrm{CD}}$ & 0.44 & $0.307 / 0.034$ & 50.00 & $0.0195^{*}$ & 1 \\
\hline
\end{tabular}



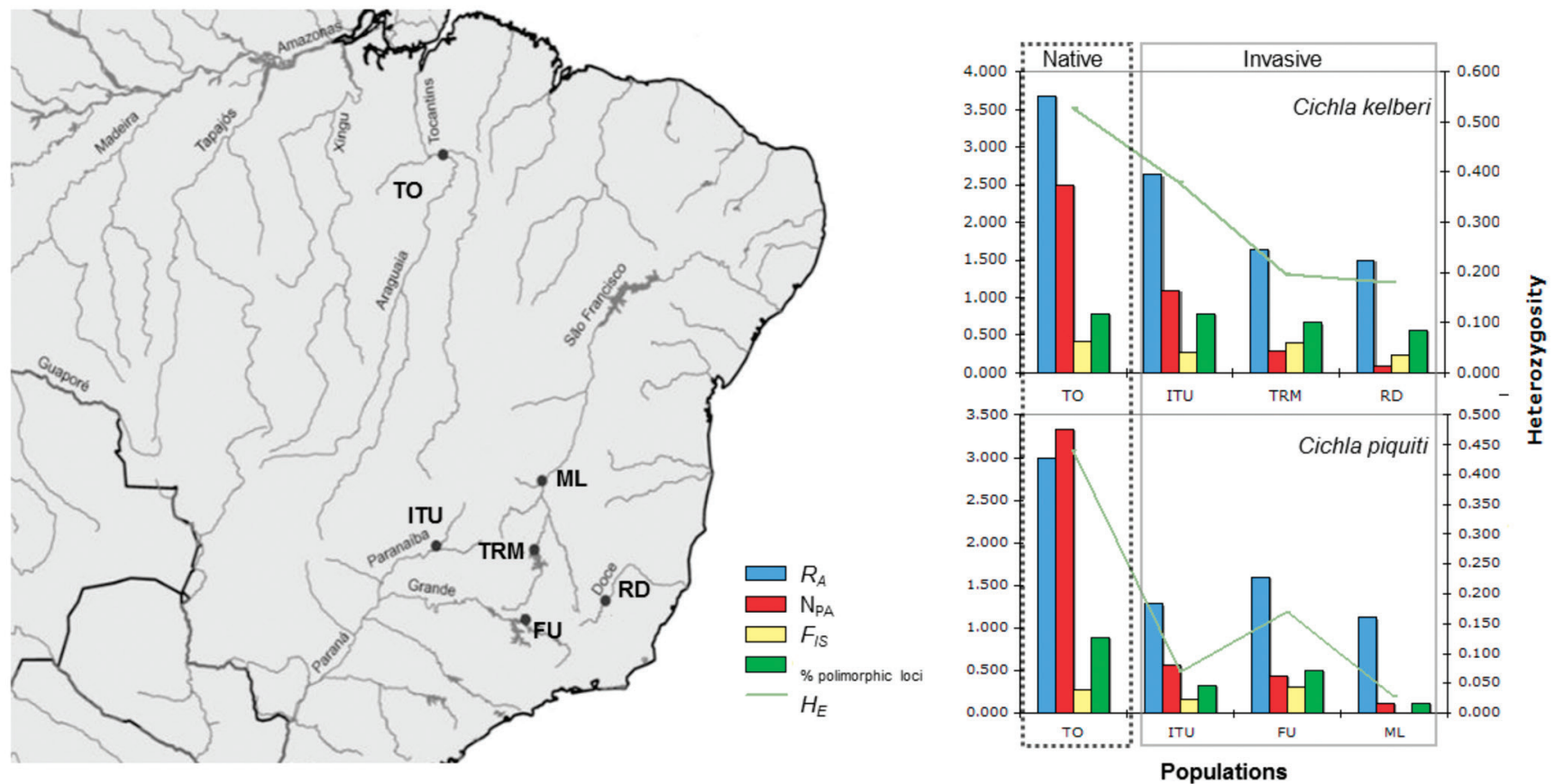

Fig. 1. River basins in eastern and northern Brazil showing sample sites and genetic parameters of native and introduced populations: Allelic richness $\left(\mathrm{R}_{\mathrm{A}}\right)$, Nei's genetic diversity $\left(\mathrm{H}_{\mathrm{E}}\right)$, Number of private alleles $\left(\mathrm{N}_{\mathrm{PA}}\right)$ and percentage of polymorphic loci. Samples sites: TRM - Três Marias reservoir and ML - Marginal Lake (both in the São Francisco River); ITU - Itumbiara reservoir (Paraná River - upper Paraná River basin); RD - Rio Doce (Dom Helvécio Lake - Doce basin); FU - Furnas reservoir (Grande River - upper Paraná River basin); TO - Tucuruí reservoir (Tocantins River - Amazon basin).

Fstat 2.9 (Goudet, 1995). To better assess levels of genetic structure in situations where null alleles were identified, we used $\mathrm{F}_{\mathrm{ST}}$ ENA estimated using the "ENA" (Excluding Null Alleles) adjustment as described in (Chapuis \& Estoup, 2007) and implemented in Freena (http://www.montpellier. inra.fr/URLB/). Since several introductions events are likely to increase the genetic divergence among populations (Wade \& Mccauley, 1988), $\mathrm{F}_{\mathrm{ST}}$ values are expected to indicate to what extent a colonization process may globally modify the partition of genetic diversity, within and between populations. Low $\mathrm{F}_{\mathrm{ST}}$ values may be consequence of a high number of founder specimens and/or high propagule pressure mediated by human dispersal (Le Corre \& Kremer, 1998), whereas high $\mathrm{F}_{\mathrm{ST}}$ values suggest low propagule pressure and cumulative founder effects.

A Bayesian model-based clustering method implemented in Structure (Pritchard et al., 2000) was conducted to determine if there was evidence for hybridization between $\mathrm{CP}$ and $\mathrm{CK}$ in the native and in introduced populations. The $\mathrm{q}$-values (i.e., the ancestry of individual fish which estimates the proportion of an individual's genotype) were inferred based on genotyped specimens assigned to two species groups $(\mathrm{k}=2$; i.e., $\mathrm{CK}$ and $\mathrm{CP}$ ) using 500000 burn-ins and 1000000 repetitions. We used a conservative $q$-value threshold of $\leq 0.05$ to identify individuals (i.e., $\mathrm{q}=0.95$ for $\mathrm{CP} ; \mathrm{q}=0.05$ for $\mathrm{CK}$ ) following (Schwartz \& Beheregaray, 2008).
Two methods implemented in Bottleneck version 1.2.02 (Piry et al., 1999) were used to detect population bottlenecks. The first method is based on the detection of 'heterozygosity excess'. In a recently bottlenecked population, the observed heterozygosity is higher than the heterozygosity expected from the observed number of alleles under the assumption of a population at mutation-drift equilibrium (Cornuet \& Luikart, 1996). The results obtained separately for each locus were combined using the Wilcoxon test (Cornuet \& Luikart, 1996; Piry et al., 1999). Second, we used a qualitative descriptor of allele frequency distribution (the mode-shift indicator), which discriminates between bottlenecked and stable populations. For a stable population, it is assumed that the rare allele is the most common, whereas in a recently bottlenecked population, intermediate classes are better represented (Luikart \& Cornuet, 1998; Luikart et al., 1998). A shift in the mode of the distribution of allelic frequency classes is thus expected.

\section{Results}

\section{Genetic diversity and population structure}

\section{Cichla kelberi}

For CK, a mean of 5 alleles per locus was observed in the invasive populations, compared to 5.6 alleles in the natives 
Table 2. Pairwise Fixation Index for native and invasive populations of $C$. kelberi (A) and C. piquiti (B). The first value is the estimate $\mathrm{F}_{\mathrm{ST}}$ of Weir (1996) and the second is the $\mathrm{F}_{\mathrm{ST}}{ }^{\mathrm{ENA}}$ using ENA correction (Chapuis \& Estoup, 2007).

(A) C. kelberi

\begin{tabular}{|c|c|c|c|c|c|}
\hline & TO & ITU & TRM & $\mathrm{RD}$ & \\
\hline TO & 0 & & & & \\
\hline ITU & $\begin{array}{c}0.3020 / 0.298 \\
(\mathrm{P}=0.002)\end{array}$ & 0 & & & \\
\hline TRM & $\begin{array}{c}0.3472 / 0.329 \\
(\mathrm{P}=0.002)\end{array}$ & $\begin{array}{c}0.5469 / 0.522 \\
(\mathrm{P}=0.002)\end{array}$ & 0 & & \\
\hline $\mathrm{RD}$ & $\begin{array}{c}0.3335 / 0.335 \\
(\mathrm{P}=0.001)\end{array}$ & $\begin{array}{c}0.5418 / 0.519 \\
(\mathrm{P}=0.002)\end{array}$ & $\begin{array}{c}0.3143 / 0.277 \\
(\mathrm{P}=0.002)\end{array}$ & 0 & Mean $=0.40 / 0.38$ \\
\hline
\end{tabular}

(B) C. piquiti

\begin{tabular}{cccccc}
\hline & TO & ITU & ML & FU & \\
\hline TO & 0 & & & & \\
ITU & $0.4376 / 0.432$ & 0 & & & \\
& $(\mathrm{P}=0.002)$ & & & & \\
ML & $0.5716 / 0.578$ & $0.8061 / 0.799$ & & & \\
& $(\mathrm{P}=0.002)$ & $(\mathrm{P}=0.002)$ & $0.6631 / 0.652$ & 0 & Mean $=0.51 / 0.51$ \\
FUR & $0.4937 / 0.476$ & $(\mathrm{P}=0.002)$ & $(\mathrm{P}=0.03)$ & & \\
& $(\mathrm{P}=0.002)$ & & & \\
\hline
\end{tabular}

range. When considering introduced and native populations a low number of alleles per locus (2.36 in average) and low Nei's genetic diversity were recovered (mean of 0.33 ). The percentage of polymorphic loci ranged from $56 \%$ to $89 \%$ and allelic richness ranged from 1.5 to 3.68 . Significant deviations from Hardy-Weinberg genotypic proportions were always associated with positive $F_{\text {IS }}$ values (Table 1). The highest $\mathrm{F}_{\mathrm{ST}}$ value was observed between Três Marias and Itumbiara, and the lowest between Itumbiara and Tocantins (average $\mathrm{F}_{\mathrm{ST}}$ of $0.40)$ (Table 2A). $\mathrm{F}_{\mathrm{ST}}^{\mathrm{ENA}}$, using ENA correction (Chapuis \& Estoup, 2007), were consistent with $\mathrm{F}_{\mathrm{ST}}$ values estimated according with (Weir, 1996) (Table 2A).

\section{Cichla piquiti}

For CP, a low mean allelic richness of 1.75 and Nei's genetic diversity (mean of 0.177 ) were recovered. The percentage of polymorphic loci ranged from $11 \%$ to $50 \%$. As in $\mathrm{CK}$, the significant deviations from Hardy-Weinberg genotypic proportions were always associated with positive $F_{\text {IS }}$ values (Table 1). An average $\mathrm{F}_{\mathrm{ST}}$ and $\mathrm{F}_{\mathrm{ST}}{ }^{\mathrm{ENA}}$ of 0.51 were recovered (Table 2B). The highest value $(80 \%)$ was observed between Itumbiara and Marginal Lake (São Francisco River), and the lowest (9\%) between Furnas and Marginal Lake (Table 2B).

\section{Null alleles}

Microcheker detected the presence of null alleles but rejected the existence of large allele dropout or scoring errors within CP. Only the native population showed evidence for null alleles (loci Tuc 10, 2, 18 - Supplement 1). For CK, only locus Tuc 13 consistently showed null alleles in more than one population. However, the $\mathrm{F}_{\mathrm{ST}}{ }^{\mathrm{ENA}}$ estimation with ENA adjustment had no differences in $\mathrm{F}_{\mathrm{ST}}$ for both species (Table 2). Using the software Inest, which estimates inbreeding and null allele frequencies to account for deviations from HWE (Supplement 1), five loci were positive for null alleles (Tuc9, Tuc 8, Tuc 3, Tuc 13, Tuc 16), but none of them had consistent results over all populations.

Our adjustment of Weir's $\mathrm{F}_{\mathrm{ST}}$ carried out with ENA in the present data $\left(\mathrm{F}_{\mathrm{ST}}^{\mathrm{ENA}}\right)$ did not show any bias due to null alleles. Therefore, the high values of $\mathrm{F}_{\mathrm{ST}}$ recovered could reliably

Table 3. Bottleneck tests. Results of two methods assessing bottlenecks in Cichla populations in the invasive range for both species $(\mathrm{ITU}=$ Itumbira; TRM $=$ Três Marias; RD = Rio Doce; $\mathrm{ML}=$ Marginal Lake; FUR = Furnas). *significant values $(\mathrm{P}=0.05)$.

\begin{tabular}{lccc}
\hline Sample & Sample size & Mode-shift $^{\S}$ & Heterozygosity excess $^{\dagger}$ \\
\hline C. kelberi $^{\dagger}$ & & & \\
ITU & 18 & Normal & 0.71094 \\
TRM & 16 & Normal & 0.34375 \\
RD & 15 & Normal & 0.59375 \\
C. piquiti & & & \\
ITU & 20 & Normal & 0.06250 \\
ML & 11 & Normal & 0.25000 \\
FUR & 10 & shifted & $0.01563^{*}$ \\
\hline
\end{tabular}


indicate low gene flow between introduced sites, suggesting that only one introduction act might be responsible for the establishment of a new invasive population of peacock bass at each site.

\section{Bottleneck}

Statistical evidence of a bottleneck was detected within $\mathrm{CP}$ for the introduced population at Furnas Reservoir, based on the Wilcoxon test under the two-phase, stepwise mutation model and shifted distribution of allelic frequency classes. Within CK populations, no statistical support for bottleneck was recovered (Table 3).

\section{Native $v s$ invasive range}

A clear pattern of reduction of genetic diversity was observed in all invasive populations for both Cichla species (Fig. 1). The percentage of polymorphic loci were high in native populations of $\mathrm{CK}$ and $\mathrm{CP}$ (78 and $89 \%$, respectively) but varied widely in the invasive range (77.8-11.1\%) (Table 1). A mean of 2.7 alleles per locus were observed in invasive populations, compared to 4.6 in the native populations of CP. Alleles detected in the introduced range were not always detected in native populations, but the great majority of private alleles were exclusive to the native populations (30 alleles or $75 \%$ ). Mean $\mathrm{F}_{\mathrm{IS}}$ varied from -0.07 to 0.279 (Table 1).

Mean allelic richness was significantly lower in populations in the invasive range $(\mathrm{CK}=1.923 ; \mathrm{CP}=1.33)$ compared with the native range $(\mathrm{CK}=3.68 ; \mathrm{CP}=2.63)(\mathrm{z}=3.543, \mathrm{P}<0.0001$; $\mathrm{z}=2.131 . \mathrm{P}=0.033)($ Table 1$)$. Nei's genetic diversity $\left(\mathrm{H}_{\mathrm{E}}\right)$ was marginally significant in the invasive range when compared to the native populations considering $\mathrm{CP}\left(\mathrm{H}_{\mathrm{E}}=0.179 / 0.44\right.$ respectively; $\mathrm{z}=1.972, \mathrm{P}=0.049$ ), but not significant for $\mathrm{CK}$ $\left(\mathrm{H}_{\mathrm{E}}=0.258 / 0.536\right.$ respectively; $\left.\mathrm{z}=0.641, \mathrm{P}=0.521\right)$. The highest values of $H_{E}$ and $R_{A}\left(H_{E}=0.393 ; R_{A}=2.63\right.$; Table 1$)$ for $C K$ in the invasive range were detected in the Itumbiara reservoir (upper Paraná River basin), the closest site to the native species. In contrast, a significant reduction in $\mathrm{H}_{\mathrm{E}}$ and $\mathrm{R}_{\mathrm{A}}$ was detected for $\mathrm{CP}$ at the same site $\left(\mathrm{H}_{\mathrm{E}}=0.07 ; \mathrm{R}_{\mathrm{A}}=1.28\right.$; Table 1$)$, possibly due to lower propagule pressure. For $\mathrm{CP}$, the highest values of $\mathrm{H}_{\mathrm{E}}$ and $\mathrm{R}_{\mathrm{A}}$ were detected in the invasive population of Furnas reservoir $\left(\mathrm{H}_{\mathrm{E}}=0.169 ; \mathrm{R}_{\mathrm{A}}=1.59\right)$, which is also part of the upper Paraná River Basin, despite the small number of specimens analyzed $(\mathrm{N}=10)$. Interestingly, within the invasive range, populations from non-impacted sites (pristine lakes) had the lowest $H_{E}, R_{A}$ and $F_{I S}$ values ( $R D$ and ML, Table 1). Strong genetic structure was detected within invasive populations and also when comparing invasive with natives. The overall $\mathrm{F}_{\mathrm{ST}}$ and $\mathrm{F}_{\mathrm{ST}}^{\text {ENA }}$ had identical or very similar values for both species $(\mathrm{CK}=0.40 / 0.38$ and $\mathrm{CP}=0.51 / 0.51$, respectively).

A significant deviation from Hardy-Weinberg equilibrium was found at locus Tuc 18, but only in the native population. Only one locus (Tuc 4) out of nine was monophorphic in the native population, whereas several loci were monomorphic in the invasive range (Supplement 1). The locus Tuc 18 had significant deviation from Hardy-Weinberg genotypic proportions associated with positive $F_{\text {IS }}$ values.

\section{Admixture analysis}

Our analysis identified two putative hybrids between CP and $\mathrm{CK}$ in the native population (fish 152, $\mathrm{q}<0.95$ and fish 63 $\mathrm{q}>0.05$, Fig. 2). No evidence of hybridization was detected in the invasive populations, even in the Itumbiara reservoir - the only site within the introduced populations where CK and CP were detected in sympatry.

\section{Discussion}

\section{Genetic diversity in native vs invasive populations}

The genetic consequences of a range expansion depend on the relative magnitudes of the number of colonists and migrants, similar to the extinction and colonization process (Wade \& Mccauley, 1988). These consequences are far

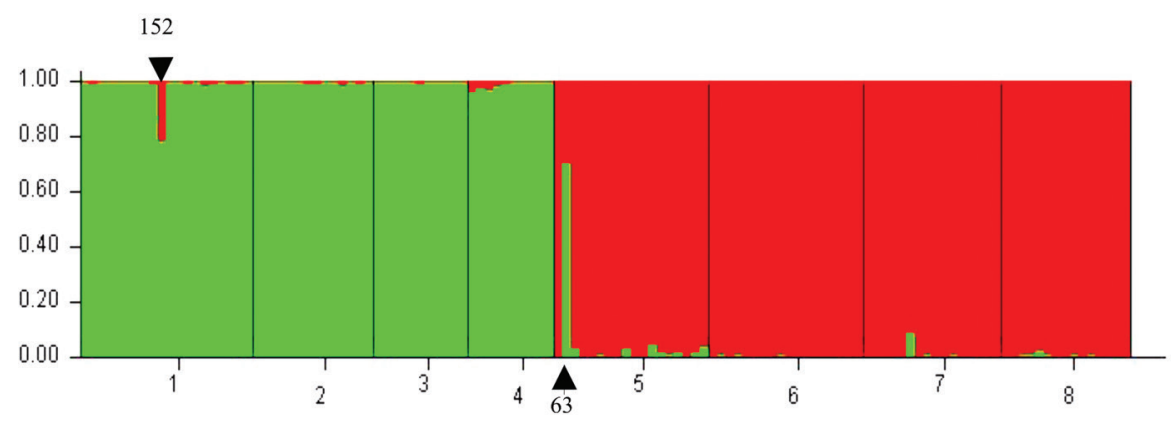

Fig. 2. Structure bar plots of probabilities of assignment of each individual from populations of CP in green (1 - TOC, 2 - ITU, 3 - ML and 4 - FU) and CK in red (5 - TOC, 6 - ITU, 7 - TRM, 8 - RD). Probabilities of assignment (q) of each individual to each cluster are shown along the $\mathrm{x}$-axis. 
more pronounced and lasting in the linear stepping-stone model than in the island model. Therefore, comparison of the genetic composition of native species with their recently established populations provide valuable information about the process of invasion (Kirkpatrick \& Barton, 1997). Here, we show a heterogeneous pattern of genetic diversity in the invasive range of two species of the apex predator genus Cichla (Fig. 1).

Nei's genetic diversity $\left(\mathrm{H}_{\mathrm{E}}\right)$ was lower in the invasive range when compared to the native populations $\left(\mathrm{CP} \mathrm{H}_{\mathrm{E}}=0.179 / 0.44\right.$; $\mathrm{CK}_{\mathrm{E}}=0.258 / 0.536$ respectively), probably due to founder effects during introduction or lower propagule pressure. Despite the reduction in genetic diversity, the population from the Itumbiara reservoir (the only site where the two species are found in sympatry) and the Furnas reservoir had levels of genetic diversity not significantly different to the native population (Table 1). The similarity in the genetic composition in Itumbiara can be attributed to multiple introductions at this site with fish from Tocantins River (Carvalho et al., 2009b).

Interestingly, both sites with no significant reduction in genetic diversity are located in the same river basin (upper Paraná River). However, Furnas is the only one out of these sites that shows a bottleneck signature (Table 3 ). This probably relates to its greater distance from the native populations, with bottleneck signal still persisting due to a likely recent population foundation.

Evidence of hybridization was detected in the native population (Fig. 2). This is in accordance with our morphological observations, since intermediate morphotypes were observed within the native range only. Carvalho et al. (2009b) also did not find any evidence of shared haplotypes within CP and CK invasive populations, even in areas of sympatry. Besides the relatively small number of fish analyzed (mean=15.3, Table 1), evidence suggests that hybridization is not an important factor in the invasive capability of Cichla.

Since cumulative founding events are predicted to lead to allele losses, the percentage of polymorphic loci and allelic richness might decrease within each translocation of a species (Le Corre \& Kremer, 1998). The heterogeneous pattern of genetic diversity in the invasive range (Fig. 1) together with high $\mathrm{F}_{\mathrm{ST}}$ values, suggests that the introduction of peacock bass agrees with a pattern of dispersal named as "jump dispersal" (Wilson et al., 2009). Here, long-distance dispersal may occur over substantial distances, but a connection (i.e., gene flow) between the new and original ranges could remain with differentiated propagule pressure (Wilson et al., 2009). For instance, average $F_{S T}$ for both species were high, with mean values of 0.4 and 0.5 for $\mathrm{CK}$ and $\mathrm{CP}$ (Table 2) respectively, suggesting low gene flow between introduced sites, but different propagule pressure between introduced and source populations appears to be occurring (Fig. 1). The initial propagule size and the occurrence of limited gene flow between established populations, in the present case, seem to be an important factor explaining the genetic patterns observed in the invasive range.

\section{Pristine vs. impacted sites}

Interestingly, the lowest value of $\mathrm{F}_{\mathrm{IS}}, \mathrm{H}_{\mathrm{E}}, \mathrm{R}_{\mathrm{A}}$ and percentage of polymorphic loci were detected in the marginal lake in the São Francisco reservoir. Marginal lakes are temporary natural lakes formed by river flooding, which might completely dry out during long drought periods. Moreover, the income of new species into marginal lakes is not frequent, limiting the propagule pressure of invasive species due to human introductions. The marginal lake analyzed here is also far from the urban centers, which might prevent recurrent introductions. At this site, the presence of only one polymorphic marker indicated that only a few specimens were responsible for the establishment of this population, with no further new introductions, leading to extremely low genetic diversity. Similar results were observed for the brown trout (Salmo trutta) introduced into Patagonia National Parks (Argentina). In this case, plasticity in life-history such as flexibility in migratory behavior and spawning, seem to be more important to the invasive process than genetic variability (Valiente et al., 2010).

Using human density as a proxy for propagule pressure, (Espinola et al., 2010) did not found any association between invasibility with human density in an analysis of 38 reservoirs invaded by CK. Likewise, we found that propagule pressure appears unimportant in the peacock bass establishment, even in pristine sites where greater resilience to invasions would be expected (i.e., Doce River and Marginal Lake). Is interesting to note that in the Pantanal (the world's largest wetland ecosystem), where more than 260 fish species occur (Britski et al., 1997) evidence suggest that a co-existence among $\mathrm{CP}$ and native fishes will be reached in the long term (Resende et al., 2008). Other examples of biotic resistance have been reported in marine (Stachowicz et al., 1999; Hunt \& Yamada, 2003), freshwater (Harvey et al., 2004; Yonekura et al., 2004) and terrestrial (Lake \& O’Dowd, 1991; Parker et al., 2006) ecosystems.

\section{Since neutral genetic diversity appear unimportant in Cichla's invasive capability, what makes Cichla an invasive species?}

We speculate that the lack of previous ontogenetic exposure of native species to a sympatric invasive predator, due to the distinct co-evolutionary history, may unable prey to recognize and respond to predators, an effect named "prey naiveté" (Cox $\&$ Lima, 2006). The lack of avoidance behavior of native prey will therefore lead to increase predation and mortality of native species. For example, in New Zealand after the introduction of brown trout (approximately 120 years ago), crayfish (Paranephrops zealandicus) were unable to recognize chemical 
cues of the invasive species (Shave et al., 1994). On the other hand, prey may recognize predators without prior exposure, what may explain induced habitat shifts in native prey (Galaxias auratus, Stuart-Smith et al., 2008). However, (Kovalenko et al., 2010) showed that prey naiveté might not be an important factor in the invasibility of peacock bass, since native prey could recognize Cichla kelberi as a predator, showing avoidance behavior. However, since prey was collected from the wild, and experiments were conducted in laboratory conditions, it is possible that prey might have previously encountered peacock bass and learned to avoid it, as pointed out by the authors (Kovalenko et al., 2010).

Many studies have shown that invaders have a superior ability to exploit local resources when compared with native residents (Byers, 2000; Kupferberg, 1997; Petren \& Case, 1996). Competitive ability is, therefore, a trait that may confer an advantage for invasive species during establishment. Differences between the competing species in the home range and those in the new range may influence an invader's success and their ability to dominate a community. Decision-making rules, also named "Darwinian algorithms" (Cosmides \& Tooby, 1987), are predicted to be adaptive, since they depend on cues that might change over evolutionary time, interfering in the survival and reproductive success of species (Williams $\&$ Nichols, 1984). Particularly important, are some biological aspects (e.g., intense reproductive activity, biparental care of eggs and capability of adaptation to harsh ecological conditions) that make Cichla a potential invasive apex predator (Munoz et al., 2006; Resende et al., 2008; Vieira et al., 2009; Zaret, 1980), as also shown for the brown trout introduced in Patagonia (Valiente et al., 2010).

When considering environments that have rapidly changed (i.e., reservoirs) or received invasive species, preliminary characteristics and adaptations of native species might no longer be advantageous. In such cases, native organisms can become "trapped" by their evolutionary responses and unable to rapidly adapt and compete with the invasive species, resulting in reduced survival and in long term extinction of native species (Schlaepfer et al., 2005).

Another important aspect in the adaptability to new environmental conditions that should be considered is Cichla's opportunistic feeding behavior (Resende et al., 2008) and cannibalism (Gomiero \& Braga, 2004). For example, it was observed that cannibalism is more accentuated during Cichla's spawning periods and due to scarcity of alternative food items, such as small individuals of small native fish species (Gomiero \& Braga, 2004; Villares Junior \& Gomiero, 2010). On the other hand, low rates of cannibalism occur in natural environments and in invaded sites mainly due to high availability of prey (Resende et al., 2008; Winemiller et al., 1997; Zaret, 1977).

Our work indicates that in Cichla, invasiveness capability is not influenced by genetic diversity (as a proxy to propagule pressure within distinct environments conditions) and hybridization. It is suggested that a combination of other factors, such as Cichla's reproductive strategies, feeding opportunistic behavior, cannibalism of young, the "evolutionary trap" effect and relatively low species richness in the invaded native ecosystems, are key in this apex predator invasion phenomenon to overcome low propagule pressure.

\section{Acknowledgments}

The authors are grateful to several artisanal fishermen for their help with the sampling and to Arno Soares, José Enemir Santos, Daniel Crepaldi and CEMIG (Companhia Energética de Minas Gerais - Programa Peixe Vivo) for providing samples. This work was supported by Conselho Nacional de Desenvolvimento Científico e Tecnológico - CNPq (process numbers INCT 573899/2008-8 and 482852/2011-9) and Fundação de Amparo à Pesquisa do Estado de Minas Gerais - FAPEMIG (process number INCT APQ-0084/08).

\section{Literature Cited}

Agostinho, A. A., H. F. Julio \& M. Petrere. 1994. Itaipu reservoir (Brazil): impacts of the impoundment on the fish fauna and fisheries. Pp. 161184. In: Cows, I. G. (Ed.). Rehabilitation of Freshwater Fisheries. Oxford: Fishing News Books.

Allendorf, F. W. \& L. L. Lundquist. 2003. Introduction: Population biology, evolution, and control of invasive species. Conservation Biology, 17: 24-30.

Banks, S. C., S. D. Ling, C. R. Johnson, M. P. Piggott, J. E. Williamson \& L. B. Beheregaray. 2010. Genetic structure of a recent climate change-driven range extension. Molecular Ecology, 19: 2011-2024.

Beheregaray, L. B. \& P. Sunnucks. 2000. Microsatellite loci isolated from Odontesthes argentinensis and the $O$. perugiae species group and their use in other South American silverside fish. Molecular Ecology, 9: 629-631.

Brinn, M. N. A., J. I. R. Porto \& E. Feldberg. 2004. Karyological evidence for interspecific hybridization between Cichla monoculus and C. temensis (Perciformes, Cichlidae) in the Amazon. Hereditas, 141: 252-257.

Britski, H. A., K. Z. S. Silimon \& B. S. Lopes. 1997. Manual de identificação de peixes do Pantanal Mato-Grossense. EMBRAPA, Corumbá.

Byers, J. E. 2000. Competition between two estuarine snails: Implications for invasions of exotic species. Ecology, 81: 1225-1239.

Carvalho, D. C., D. A. A. Oliveira, I. Sampaio \& L. B. Beheregaray. 2009a. Microsatellite markers for the Amazon peacock bass (Cichla piquiti). Molecular Ecology Resources, 9: 239-241.

Carvalho, D. C., D. A. A. Oliveira, J. E. Santos, P. Teske, L. B. Beheregaray, H. Schneider \& I. Sampaio. 2009b. Genetic characterization of native and introduced populations of the neotropical cichlid genus Cichla in Brazil. Genetics and Molecular Biology, 32: 601-607.

Chapuis, M. P. \& A. Estoup. 2007. Microsatellite null alleles and estimation of population differentiation. Molecular Biology and Evolution, 24: 621-631.

Chellappa, S., M. R. Câmara, N. T. Chellappa, M. C. M. Beveridge \& F. A. Huntingford. 2003. Reproductive ecology of a neotropical 
cichlid fish, Cichla monoculus (Osteichthyes: Cichlidae). Brazilian Journal of Biology, 63: 17-26.

Chybicki, I. J. \& J. Burczyk. 2009. Simultaneous estimation of null alleles and inbreeding coefficients. Journal of Heredity, 100: 106-113.

Cosmides, L. \& J. Tooby. 1987. From evolution to behaviour: evolutionary psychology as the missing link. Pp. 277-306. In: Dupré, J. (Ed.), The latest on the Best: Essays on Evolution and Optimality. MIT Press, Cambridge, MA.

Cox, J. G. \& S. L. Lima. 2006. Naivete and an aquatic-terrestrial dichotomy in the effects of introduced predators. Trends in Ecology \& Evolution, 21: 674-680.

Dlugosch, K. M. \& I. M. Parker. 2008. Founding events in species invasions: genetic variation, adaptive evolution, and the role of multiple introductions. Molecular Ecology, 17: 431-449.

Espinola, L. A., C. V. Minte-Vera \& H. F. Julio. 2010. Invasibility of reservoirs in the Paraná Basin, Brazil, to Cichla kelberi Kullander and Ferreira, 2006. Biological Invasions, 12: 1873-1888.

Gaskin, J., M. Schwarzländer, L. Williams, E. Gerber \& H. Hinz. 2012. Minimal genetic diversity in the facultatively outcrossing perennial pepperweed (Lepidium latifolium) invasion. Biological Invasions: 1-11.

Gomiero, L. M. \& F. M. S. Braga. 2004. Cannibalism as the main feeding behaviour of tucunares introduced in Southeast Brazil. Brazilian Journal of Biology, 64: 625-632.

Henry, P., G. Le Lay, J. Goudet, A. Guisan, S. Jahodova \& G. Besnard. 2009. Reduced genetic diversity, increased isolation and multiple introductions of invasive giant hogweed in the western Swiss Alps. Molecular Ecology, 18: 2819-2831.

Kirkpatrick, M. \& N. H. Barton. 1997. Evolution of a species' range. American Naturalist, 150: 1-23.

Kolbe, J. J., R. E. Glor, L. Rodriguez Schettino, A. C. Lara, A. Larson \& J. B. Losos. 2004. Genetic variation increases during biological invasion by a Cuban lizard. Nature, 431: 177-181.

Kovalenko, K. E., E. D. Dibble, A. A. Agostinho \& F. M. Pelicice. 2010. Recognition of non-native peacock bass, Cichla kelberi by native prey: testing the naivet, hypothesis. Biological Invasions, 12: 3071-3080.

Kupferberg, S. J. 1997. Bullfrog (Rana catesbeiana) invasion of a California river: The role of larval competition. Ecology, 78: 1736-1751.

Latini, A. O. \& M. Petrere. 2004. Reduction of a native fish fauna by alien species: an example from Brazilian freshwater tropical lakes. Fisheries Management and Ecology, 11: 71-79.

Le Corre, V. \& A. Kremer. 1998. Cumulative effects of founding events during colonisation on genetic diversity and differentiation in an island and stepping-stone model. Journal of Evolutionary Biology, 11: 495-512.

Lockwood, J. L., P. Cassey \& T. Blackburn. 2005. The role of propagule pressure in explaining species invasions. Trends in Ecology \& Evolution, 20: 223-228.

Munoz, H., P. A. Van Damme \& F. Duponchelle. 2006. Breeding behaviour and distribution of the tucunare Cichla aff. monoculus in a clear water river of the Bolivian Amazon. Journal of Fish Biology, 69: 1018-1030.

Okada, M., M. Lyle \& M. Jasieniuk. 2009. Inferring the introduction history of the invasive apomictic grass Cortaderia jubata using microsatellite markers. Diversity and Distributions, 15: 148-157.

Petren, K. \& T. J. Case. 1996. An experimental demonstration of exploitation competition in an ongoing invasion. Ecology, 77: 118-132.

Pompeu, P. D. S. \& A. L. Godinho. 2001. Mudança na dieta da traira
Hoplias malabaricus (Bloch) (Erythrinidae, Characiformes) em lagoas da bacia do rio Doce devido a introdução de peixes piscívoros. Revista Brasileira de Zoologia, 18: 1219-1225.

Pritchard, J. K., M. Stephens \& P. Donnelly. 2000. Inference of population structure using multilocus genotype data. Genetics, 155: 945-959.

Resende, E. K., D. K. S. Marques \& L. K. S. G. Ferreira. 2008. A successful case of biological invasion: the fish Cichla piquiti, an Amazonian species introduced into the Pantanal, Brazil. Brazilian Journal of Biology, 68: 799-805.

Rousset, F. 2008. GENEPOP 007: a complete re-implementation of the GENEPOP software for Windows and Linux. Molecular Ecology Resources, 8: 103-106.

Sakai, A. K., F. W. Allendorf, J. S. Holt, D. M. Lodge, J. Molofsky, K. A. With, S. Baughman, R. J. Cabin, J. E. Cohen, N. C. Ellstrand, D. E. McCauley, P. O’Neil, I. M. Parker, J. N. Thompson \& S. G. Weller. 2001. The Population Biology of Invasive Specie. Annual Review of Ecology and Systematics, 32: 305-332.

Sambrook, J., E. F. Fritish \& T. Maniatis. 1989. Molecular cloning: a laboratory manual. Cold Spring Harbor, Cold Spring Harbor Laboratory Press.

Sax, D. F., J. J. Stachowicz \& S. D. Gaines. 2005. Species invasions: insights into ecology, evolution, and biogeography. Sunderland, Mass., Sinauer Associates.

Schlaepfer, M. A., P. W. Sherman, B. Blossey \& M. C. Runge. 2005. Introduced species as evolutionary traps. Ecology Letters, 8: 241-246.

Schuelke, M. 2000. An economic method for the fluorescent labeling of PCR fragments. Nature Biotechnology, 18: 233-234.

Schwartz, T. S. \& L. B. Beheregaray. 2008. Using genotype simulations and Bayesian analyses to identify individuals of hybrid origin in Australian bass: lessons for fisheries management. Journal of Fish Biology, 72: 435-450.

Suarez, A. V. \& N. D. Tsutsui. 2008. The evolutionary consequences of biological invasions. Molecular Ecology, 17: 351-360.

Valiente, A. G., F. Juanes, P. Nunez \& E. Garcia-Vazquez. 2010. Brown trout (Salmo trutta) invasiveness: plasticity in life-history is more important than genetic variability. Biological Invasions, 12: 451-462.

Van Oosterhout, C., W. F. Hutchinson, D. P. M. Wills \& P. Shipley. 2004. MICRO-CHECKER: software for identifying and correcting genotyping errors in microsatellite data. Molecular Ecology Notes, 4: 535-538.

Vieira, A. B. C., L. F. Salvador, Jr., R. M. C. Melo, G. B. Santos \& N. Bazzoli. 2009. Reproductive biology of the peacock bass Cichla piquiti (Perciformes: Cichlidae), an exotic species in a Neotropical reservoir. Neotropical Ichthyology, 7: 745-750.

Villares Junior, G. A. \& L. M. Gomiero. 2010. Feeding dynamics of Cichla kelberi Kullander \& Ferreira, 2006 introduced into an artificial lake in Southeastern Brazil. Neotropical Ichthyology, 8: 819-824.

Wade, M. J. \& D. E. Mccauley. 1988. Extinction and Recolonization Their Effects on the Genetic Differentiation of Local-Populations. Evolution, 42: 995-1005.

Weir, B. 1996. Intraspecific Differentiation. Pp. 385-406. In: Moritz, C. \& B. Mable (Eds.). Molecular Systematics. Sinauer Associates, Massachusetts.

Williams, B. K. \& J. D. Nichols. 1984. Optimal Timing in Biological Processes. American Naturalist, 123: 1-19.

Wilson, J. R. U., E. E. Dormontt, P. J. Prentis, A. J. Lowe \& D. M. Richardson. 2009. Something in the way you move: dispersal pathways affect invasion success. Trends in Ecology \& Evolution, 24: 136-144. 
Winemiller, K. O., D. C. Taphorn \& A. Barbarino-Duque. 1997. Ecology of Cichla (Cichlidae) in two blackwater rivers of southern Venezuela. Copeia, 1997: 690-696.

Zaret, T. M. 1977. Inhibition of cannibalism in Cichla ocellaris and hypothesis of predator mimicry among South-American fishes. Evolution, 31: 421-437.

Zaret, T. M. 1980. Life-history and growth relationships of Cichla ocellaris, a predatory South-American cichlid. Biotropica, 12: $144-157$.

Zaret, T. M. \& R. T. Paine. 1973. Species Introduction in a Tropical Lake. Science, 182: 449-455.

Submitted July 1, 2013

Accepted October 2, 2013 by Claudio Oliveira

Published March 31, 2014 
Supplement 1. Data estimated by each locus of microsatellite loci considering every locus in all populations for both species. The follow indexes are presented: Number of alleles $\left(\mathrm{N}_{\mathrm{A}}\right)$; Inbreed coefficient $\left(\mathrm{F}_{\mathrm{IS}}\right)$, Observed heterozygosity (Ho), Expected heterozygosity (He) and null alleles. "Mono" stands for monomorphic locus. * Indicate locus out of HWE equilibrium (P=0.05) after Bonferroni adjustment.

\begin{tabular}{|c|c|c|c|c|c|c|c|c|}
\hline \multirow[b]{2}{*}{ Loci/Pop } & \multicolumn{4}{|c|}{ C. kelberi } & \multicolumn{4}{|c|}{ C. piquiti } \\
\hline & TO & ITU & TRM & $\mathrm{RD}$ & TO & ITU & ML & FUR \\
\hline \multicolumn{9}{|l|}{ Tuc12 } \\
\hline $\mathbf{N}_{\mathrm{A}}$ & 4 & 2 & 2 & 2 & 2 & 1 & 1 & 1 \\
\hline Ho & 0.8333 & 0.6000 & 0.3846 & 0.3333 & 0.0500 & Mono & Mono & Mono \\
\hline He & 0.7833 & 0.4286 & 0.3205 & 0.5000 & 0.0500 & - & - & - \\
\hline Fis & -0.0638 & -0.4000 & -0.2000 & 0.3333 & 0.0000 & - & - & - \\
\hline Null allele & no & no & no & no & no & - & - & - \\
\hline INEST & no & no & no & no & no & no & no & no \\
\hline \multicolumn{9}{|l|}{ Tuc10 } \\
\hline $\mathbf{N}_{\mathrm{A}}$ & 1 & 1 & 1 & 1 & 2 & 1 & 1 & 1 \\
\hline Ho & Mono & Mono & Mono & Mono & 0.0000 & Mono & Mono & Mono \\
\hline He & - & - & - & - & 0.1000 & - & - & - \\
\hline Fis & - & - & - & - & 1.0000 & - & - & - \\
\hline Null allele & - & - & - & - & no & - & - & - \\
\hline INEST & no & no & no & no & no & no & no & no \\
\hline \multicolumn{9}{|l|}{ Tuc9 } \\
\hline $\mathbf{N}_{\mathrm{A}}$ & 3 & 1 & 1 & 1 & 3 & 1 & 1 & 1 \\
\hline Ho & $0.0000 *$ & Mono & Mono & Mono & 0.2500 & Mono & Mono & Mono \\
\hline $\mathrm{He}$ & 0.2279 & - & - & - & 0.3333 & - & - & - \\
\hline Fis & 1.0000 & - & - & - & 0.2500 & - & - & - \\
\hline Null allele & yes & - & - & - & no & - & - & - \\
\hline INEST & yes & no & no & no & no & no & no & no \\
\hline \multicolumn{9}{|l|}{ Tuc3 } \\
\hline $\mathbf{N}_{\mathrm{A}}$ & 8 & 4 & 3 & 1 & 6 & 1 & 1 & 2 \\
\hline Ho & $0.3889 *$ & $0.5000^{*}$ & $0.0667 *$ & Mono & 0.6500 & Mono & Mono & 0.0000 \\
\hline $\mathrm{He}$ & 0.8072 & 0.7680 & 0.5381 & - & 0.6474 & - & - & 0.2000 \\
\hline Fis & 0.5182 & 0.3489 & 0.8761 & - & -0.0041 & - & - & 1.0000 \\
\hline Null allele & yes & no & yes & - & no & - & - & no \\
\hline INEST & yes & no & yes & yes & no & no & no & yes \\
\hline \multicolumn{9}{|l|}{ Tuc13 } \\
\hline $\mathbf{N}_{\mathrm{A}}$ & 6 & 9 & 1 & 1 & 9 & 1 & 1 & 2 \\
\hline Ho & $0.1765^{*}$ & $0.5556^{*}$ & Mono & Mono & 0.4500 & Mono & Mono & 0.0000 \\
\hline $\mathrm{He}$ & 0.8162 & 0.8856 & - & - & 0.6895 & - & - & 0.2000 \\
\hline Fis & 0.7838 & 0.3727 & - & - & 0.3473 & - & - & 1.0000 \\
\hline Null allele & yes & yes & - & - & yes & - & - & no \\
\hline INEST & yes & yes & no & yes & no & no & no & yes \\
\hline \multicolumn{9}{|l|}{ Tuc4 } \\
\hline $\mathbf{N}_{\mathrm{A}}$ & 1 & 2 & 2 & 2 & 1 & 2 & 3 & 2 \\
\hline Ho & Mono & $0.0000 *$ & 0.0667 & 0.0769 & Mono & 0.0714 & 0.2727 & 0.1000 \\
\hline $\mathrm{He}$ & - & 0.1111 & 0.0667 & 0.0769 & - & 0.0714 & 0.2545 & 0.1000 \\
\hline Fis & - & 1.0000 & -0.0000 & -0.0000 & - & 0.0000 & -0.0714 & 0.0000 \\
\hline Null allele & - & no & no & no & - & no & no & no \\
\hline INEST & no & no & no & no & no & no & no & no \\
\hline \multicolumn{9}{|l|}{ Tuc5 } \\
\hline $\mathbf{N}_{\mathrm{A}}$ & 8 & 5 & 2 & 3 & 6 & 4 & 1 & 3 \\
\hline Ho & 0.6667 & 0.4444 & 0.0000 & $0.0769 *$ & 0.5000 & 0.1429 & Mono & 0.2000 \\
\hline $\mathrm{He}$ & 0.8366 & 0.5327 & 0.1250 & 0.3462 & 0.7013 & 0.2720 & - & 0.3667 \\
\hline Fis & 0.2031 & 0.1656 & 1.0000 & 0.7778 & 0.2871 & 0.4747 & - & 0.4545 \\
\hline Null allele & no & no & no & no & no & no & - & no \\
\hline INEST & no & no & no & no & no & no & no & no \\
\hline \multicolumn{9}{|l|}{ Tuc16 } \\
\hline $\mathbf{N}_{\mathrm{A}}$ & 7 & 2 & 3 & 2 & 4 & 1 & 1 & 2 \\
\hline Ho & $0.3333 *$ & $0.1111 *$ & 0.2500 & 0.4000 & 0.4500 & Mono & Mono & 0.2000 \\
\hline He & 0.6029 & 0.1078 & 0.4167 & 0.4619 & 0.6132 & - & - & 0.1889 \\
\hline Fis & 0.4472 & -0.0303 & 0.4000 & 0.1340 & 0.2661 & - & - & -0.0588 \\
\hline Null allele & yes & no & no & no & no & - & - & no \\
\hline INEST & yes & no & no & no & no & no & no & no \\
\hline
\end{tabular}


Supplement 1. Cont. Data estimated by each locus of microsatellite loci considering every locus in all populations for both species. The follow indexes are presented: Number of alleles $\left(\mathrm{N}_{\mathrm{A}}\right)$; Inbreed coefficient $\left(\mathrm{F}_{\mathrm{IS}}\right)$, Observed heterozygosity (Ho), Expected heterozygosity (He) and null alleles. "Mono" stands for monomorphic locus. * Indicate locus out of HWE equilibrium $(\mathrm{P}=0.05)$ after Bonferroni adjustment.

\begin{tabular}{|c|c|c|c|c|c|c|c|c|}
\hline \multicolumn{9}{|l|}{ Tuc18 } \\
\hline $\mathbf{N}_{\mathrm{A}}$ & 12 & 5 & 2 & 2 & 8 & 2 & 1 & 2 \\
\hline Ho & 0.7059 & $0.3889 *$ & 0.3333 & 0.4167 & $0.5263^{*}$ & 0.2857 & Mono & 0.5000 \\
\hline $\mathrm{He}$ & 0.9081 & 0.7059 & 0.3939 & 0.3409 & 0.8626 & 0.2527 & - & 0.3889 \\
\hline Null allele & yes & no & no & no & yes & no & - & no \\
\hline INEST & no & no & no & no & yes & no & no & no \\
\hline \multicolumn{9}{|l|}{ Average } \\
\hline $\mathrm{He}$ & 0.5365 & 0.3926 & 0.2002 & 0.1824 & 0.4443 & 0.0701 & 0.0283 & 0.1699 \\
\hline Fis genpop & 0.4255 & 0.2792 & 0.4368 & 0.2315 & 0.2797 & 0.1613 & -0.0714 & 0.3077 \\
\hline Fis inest & 0.076 & 0.046 & 0.046 & 0.046 & 0.039 & 0.036 & 0.037 & 0.034 \\
\hline
\end{tabular}

